\title{
Resenha
}

\section{The Entrepreneurial State: Debunking Public vs Private Sector Myths}

\section{Mariana Mazzucato.}

Anthem Press: London, UK. 2013.

\section{Paula Andréa do Valle Hamberger*}

Mariana Mazzucato, professora de Economia da Inovação da SPRU, da Universidade de Sussex, apresenta nesse livro uma reviravolta no debate sobre o papel do Estado. Contesta a noção de um mercado autorregulador que não é suportado pelos exemplos históricos da origem do mercado e do seu desempenho nesse e no último século. Com base em Karl Polanyi, indica a visão de que é o Estado que permite a existência de um livre-mercado e acrescenta que o mercado está totalmente imerso no Estado que o engendra.

Focaliza, em especial, o papel do Estado no que tange à inovação. Apesar de reconhecer que a inovação não é a principal atribuição do Estado, considera o papel de empreendedor do setor público, por meio de suas potenciais características inovadoras e dinâmicas como argumentos em favor da sua existência e de sua postura ativa. O livro subdivide-se em dez capítulos, sendo o último dedicado às conclusões da autora.

Após a crise de 2007/2008, afirma a autora, algumas economias passaram a considerar que as estratégias adequadas perpassam pelo corte de programas do Governo e da diminuição de sua presença tornando as economias "mais competitivas" (embora seja preciso registrar a presença do Estado para combater a crise, em vários países afetados por ela). Em contrapartida, segundo Mazzucato, o que a história de novos setores ensina (sobretudo nos Estados Unidos, país modelo do Laissez Faire) é que somente depois que o Estado efetua os investimentos de alto risco (Knightian risk) é que as empresas privadas realizam sua entrada.

$\mathrm{Na}$ maioria das vezes, esse ingresso do setor privado ocorre somente depois que o Estado já absorveu a maior parcela do risco e da incerteza inerente à formação desses novos setores. E as áreas de mais alto risco, compostas por alta intensidade tecnológica e de capital, além de elevado risco, tendem a ser evitadas pelas empresas privadas, necessitando tanto do financiamento do Governo quanto da visão e liderança do setor público.

O intento da autora é confrontar a imagem popular do Estado como máquina burocrática com uma imagem bem distinta, que é a de um Estado líder em assumir riscos para o desenvolvimento da Economia, via geração de mudanças tecnológicas ou de suas bases. Portanto, descreve um Estado que desenvolve novas tecnologias, alicerça e respalda novas indústrias. É

\footnotetext{
* Professora Doutora da FACE - Faculdade de Administração, Contábeis e Economia da Universidade Federal de Goiás. E-mail: paula_hamberger@yahoo.com.br
} 
lógico que admite que esse não é o único papel do Estado, mas ressalta a importância de reconhecer quando o Estado atua como empreendedor, corrigindo a errônea visão de que o que o Estado faz, no máximo, é corrigir as "falhas de mercado" ou facilitar a inovação do "dinâmico" setor privado.

Nesse sentido, argumenta que o Estado lidera o processo de crescimento econômico em vez de apenas incentivar o setor privado ou estabilizar a Economia para os empreendedores efetuarem a sua "mágica". O papel do Estado consiste muito mais em assumir riscos com coragem e visão, em vez de simplesmente estabelecer as condições macroeconômicas necessárias para que outros agentes possam, então, efetuar investimentos arriscados e inovadores. De fato, a autora afirma que não somente o Governo financia as pesquisas mais arriscadas, tanto de base quanto aplicadas, como também consiste, inúmeras vezes, na fonte de inovações radicais que quebraram paradigmas ou mudaram trajetórias.

A grande diferença entre o financiamento do Governo e o de outros tipos de instituições consiste na visão temporal. O capital do Estado é denominado de "capital paciente", que investe tanto no curto como no longo prazo e, por vezes, no longíssimo prazo. Por trás de investimentos de longo prazo e de larga escala, a máquina geradora é quase sempre o Estado, neste e no último século.

No caso do Governo americano, os exemplos de Estado empreendedor são profusos, uma vez que o Estado americano desempenhou um papel preponderante no desenvolvimento tecnológico daquele país. A participação do Estado americano vai desde a doação de terras para as empresas privadas para a construção de rodovias, passando pelo suporte financeiro à pesquisa agrícola do século XX, transitando pela mobilização dos recursos, de suporte e de desenvolvimento ativo das indústrias aeronáutica, espacial e de aviões. Além disso, essa participação percorre as subvenções do Governo para P\&D, inclusive financiamento para as ciências, a nanotecnologia, a biotecnologia e as indústrias de energia limpa.

Um grande exemplo dessa participação ativa do Estado, segundo a autora, é o Silicon Valley, muito diferente da história conhecida de um aglomerado de empreendedores alimentados pelo livrearbítrio e financiados pelo "capital de risco" (venture capital). O Silicon Valley beneficiou-se da Internet que surge de um projeto do Departamento de Defesa americano (ARPANET), dos padrões de gastos federais que incentivaram e serviram de demanda para um complexo de novas tecnologias que fomentaram parecerias universidade-indústrias e deram forma à inovação tecnológica, segundo as prioridades da políticas de defesa da Guerra Fria.

Desse modo é que age o Estado empreendedor, investe em áreas até reduzir o risco amedrontador e a incerteza em mero risco, que se estende a todos os diferentes tipos de risco e incerteza das mais diversas áreas de pesquisa, uma vez que o setor público é de muitas formas mais 
empreendedor do que o setor privado. Este último furta-se ao desenvolvimento de produtos e processos mais radicais deixando a cargo do Estado os mais incertos investimentos e o "privilégio" de fazê-lo primeiro.

No caso dos computadores, para além de mero financiamento, a Agência de Projetos de Pesquisa Avançados de Defesa (DARPA) promoveu a emergência de um novo paradigma, fornecendo os recursos para a formação dos departamentos de Ciência da Computação, das empresas start-up, contribuindo para a pesquisa em semicondutores e na de interface homemcomputador, sendo ainda responsável por toda fase inicial da Internet. E, após todo esse financiamento, quando as empresas privadas iniciaram suas atividades e foram surgindo como seus desdobramentos, o Estado operou como financiador dessas empresas, além de cliente para seus produtos, de maneira a tornar viável e popularizar essa forma de avanço tecnológico.

Portanto, apesar das críticas aos perigos da presença do Estado ativo e da atitude do setor público financiando empresas "vencedoras" e ferindo o livre mercado, a autora apresenta inúmeras evidências de empresas que tiveram todas suas fundações desenvolvidas pelo Estado que, inclusive, com a entrega das ferramentas para que elas se tornassem grandes players industriais em setores de alto dinamismo tecnológico, como no caso da Apple®.

Em contraste com as tecnologias revolucionárias de informação e de comunicação que nasceram como resultado dos investimentos do Estado, a autora chama a atenção para a revolução industrial verde e o papel do Estado. Diferentemente de como se comportou em outros setores, o Estado refreia-se em desempenhar o papel de empreendedor central e assumir riscos e incertezas. E, ao deixar ao "livre mercado" a tomada de decisão, percebe-se que o setor privado rejeita levar esse processo adiante, o que explica a lentidão do processo de mudança desse paradigma. Tanto que, quando o Estado participa intensamente, como no caso das energias solar e eólica, com diferentes tipos de políticas públicas, é visível, aponta a autora, o importante papel que desempenha na origem dessas tecnologias verdes. Mas a visão de longo prazo para transformar o sistema produtivo corrente em um sistema industrial verde dependerá de uma participação de liderança ainda mais ativa do Estado empreendedor, pois assim como o setor privado, o capital de risco está desprovido dos recursos e do interesse de financiar o crescimento de energias de tecnologia limpa, via empresas intensivas em capital e pertencentes a mercados complexos, ainda menos há motivação de mobilizar recursos para uma mudança de paradigma. Tanto empresas quanto o capital de risco querem retornos rápidos e não possuem "capital paciente".

Nesse sentido, o papel do Estado como empreendedor conduz a questão de que todo empreender enfrenta em relação de risco-retorno. E qual tem sido o retorno do Estado? — pergunta a autora, em especial porque se trata de dinheiro público. A recompensa do Estado deveria ser 
múltipla, a saber: a criação de empregos, o crescimento da Economia, o retorno por meio de impostos, a melhora da qualificação do mercado de trabalho, melhores condições de vida etc. Vários problemas são enfrentados pelo Estado quanto ao resultado dos seus financiamentos à inovação. Em termos de impostos, tem-se a evasão fiscal, os lobbies por menores impostos promovido por empresas e setores, que muitas vezes foram os mais beneficiados por recursos públicos. Desse modo, como o Estado pode financiar outros avanços tecnológicos? Quanto à geração de empregos, empresas migram suas fábricas para países com mão de obra barata deixando para o país de origem postos de trabalho de baixa qualificação e, muitas vezes, sem muita expressividade numérica.

Portanto, o que se tem é uma socialização do risco e uma privatização dos retornos, e a pergunta que a autora coloca é onde está o futuro de um sistema como esse. O resultado do nexo desse tipo de sistema de risco-retorno instaurado é a iniquidade que, ao gerar grandes bolsões de injustiça, quebra o fluxo dos investimentos em inovação e resulta em instabilidade. Instabilidade que, elevada, aumenta a incerteza do processo de inovação, que resulta em declínio do crescimento da Economia.

Enfim, um livro instigante que apresenta inúmeros elementos para revermos a visão sobre o papel do Estado e com certeza gerará uma profusão de novos debates. 